\title{
Pengaruh Iklim Organisasi dan Kepemimpinan Terhadap Motivasi Kerja dan Kinerja Perawat di RS PKU Muhammadiyah Yogyakarta Unit II
}

\author{
Mega Oktiana1, Siti Dyah Handayani ${ }^{1}$ \\ Manajemen Rumah Sakit, Universitas Muhammadiyah Yogyakarta \\ Email:mega.oktiana@gmail.com
}

\begin{abstract}
Abstrak
Perawat merupakan sumber daya manusia yang penting dalam sebuah rumah sakit. Hal ini menyebabkan pelayanan keperawatan berkontribusi besar dalam menentukan kualitas kerja rumah sakit. Upaya peningkatan pelayanan rumah sakit, harus dilakukan secara beriringan dengan peningkatan kinerja perawat dalam melakukan pelayanan keperawatan. Dimana kinerja perawat sebagai ujung tombak pelayanan kesehatan merupakan masalah yang sangat penting untuk dikaii dalam rangka mempertahankan dan meningkatkan mutu pelayanan kesehatan. Jenis penelitian kausal dengan pendekatan kuantitatif. Populasi 152 perawat. Jumlah sampel semua perawat. Teknik analisis data menggunakan Structural Equation Model dengan AMOS. Hasil yang deperoleh berdasarkan nilai c.r $>1,96$ dan $p<0,05$ bahwa ada pengaruh yang signifikan antara iklim organisasi, kepemimpinan terhadap motivasi kerja dan ada pengaruh yang signifikan antara motivasi kerja, iklim organisasi, kepemimpinan terhadap kinerja perawat. Berdasarkan nilai standardized direct effect yang dilihat dalam tabel menunjukan hasil lebih besar, sehingga disimpulkan bahwa ada pengaruh langsung iklim organisasi terhadap kinerja perawat dan ada pengaruh langsung kepemimpinan terhadap kinerja perawat. Kesimpulan ada pengaruh yang signifikan iklim organisasi dan kepemimpinan terhadap motivasikerja dan kinerja perawat di RS PKU Muhammadiyah Yogyakarta unit II.
\end{abstract}

Kata Kunci: Iklim Organisasi, kepemimpinan, Motivasi, Kinerja Perawat

\section{The Effect Of Organizational Climate And Leadership On Work Motivation and Nurse Performance in PKU Muhammadiyah Yogyakarta Hospital Unit II}

\begin{abstract}
Abstrack
Nurses are important human resources in a hospital. This causes nursing services to contribute greatly in determining the quality of hospital work. Efforts to improve hospital services, must be carried out in tandem with improving the performance of nurses in carrying out nursing services. Where the performance of nurses as the spearhead of health services is a very important problem to be studied in order to maintain and improve the quality of health services. Type of causal research with quantitative approach. Population 152 nurses. Total sample of all nurses. Data analysis technique uses the Structural Equation Model with AMOS. The results obtained were based on c.r values $>1.96$ and $p<0.05$ that there was a significant influence between organizational climate, leadership, work motivation and there was a significant influence between work motivation, organizational climate, leadership on nurse performance. Based on the value of the standardized direct effect seen in the table shows greater results, so it was concluded that there is a direct influence of organizational climate on nurse performance and there is a direct influence of leadership on nurse performance. Conclusion There is a significant effect of organizational climate and leadership on work motivation and nurse performance in PKU Muhammadiyah Yogyakarta Hospital unit II.
\end{abstract}

Keywords: Organizational Climate, leadership, Motivation, Performance

Received: 28/09/2018; published: 28/10/2018 


\section{PENDAHULUAN}

Perawat merupakan sumber daya manusia yang penting dalam sebuah rumah sakit. Perawat memberikan pelayanan yang konstan dan terus menerus 24 jam kepada pasien setiap hari. Hal ini menyebabkan pelayanan keperawatan berkontribusi besar dalam menentukan kualitas kerja rumah sakit. Upaya peningkatan pelayanan rumah sakit, harus dilakukan secara beriringan dengan peningkatan kinerja perawat dalam melakukan pelayanan keperawatan (1). Langkah menghasilkan kinerja yang produktif dari setiap karyawan, maka seorang pemimpin perlu memberikan motivasi yang dapat mengarah terciptanya budaya kerja yang kuat artinya setiap karyawan harus mampu secara mandiri, kreatif dan dinamis dalam menyelesaikan tugas yang diberikan pimpinan tepat pada waktunya. Kinerja perawat dipengaruhi oleh banyak faktor.

Broni (2) menyatakan bahwa salah satu faktor paling penting yang menggerakkan manusia untuk mencapai tujuannya adalah motivasi. Iklim organisasi merupakan salah satu variabel yang mempunyai pengaruh terhadap kinerja perawat, baik secara langsung, maupun tidak langsung dengan motivasi kerja sebagai variabel antara (intervening). Pemimpinan menjalin hubungan kerja yang efektif melalui kerja sama dengan orang-orang yang dipimpinnya, sehingga semua program kerja akan terlaksana berkat bantuan orang-orang yang dipimpin Berdasarkan latar belakang masalah di atas, penulis tertarik melakukan penelitian dengan judul: Pengaruh Iklim Organisasi dan Kepemimpinan Terhadap Motivasi Kerja dan Kinerja Perawat di RS PKU Muhammadiyah Yogyakarta Unit II.

\section{BAHAN DAN METODE}

Jenis penelitian merupakan penelitian kausal dengan pendekatan kuantitatif. Populasi dalam penelitian ini adalah perawat di RS PKU Muhammadiyah Yogyakarta Unit II. Pada penelitian ini digunakan sampling jenuh, di mana seluruh anggota populasi digunakan sebagai sampel. Instrument penelitian menggunakan koesioner.

\section{HASIL DAN PEMBAHASAN}

\section{Analisis Faktor Konfirmatori Konstruk Eksogen}

Analisis faktor konfirmatori konstruk eksogen digunakan untuk menguji unidimensionalitas pembentuk masing-masing variabel laten. Pada konstruk eksogen, terhadap 2 unobserved variable dengan 17 observed variable sebagai pembentuknya. Hasil pengujian analisis faktor konfirmatory konstruk eksogen ditunjukkan pada Gambar 1 berikut: 


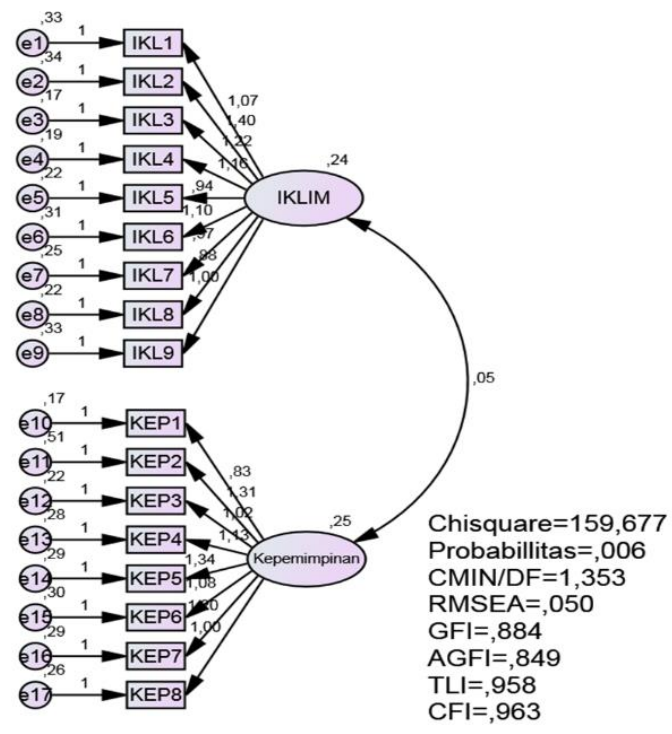

Gambar 1. Model Analisis Faktor Konfirmatori Konstruk Eksogen

Hasil uji fit model faktor konfirmatori konstruk eksogen dapat dideskripsikan dalam Tabel 1 berikut:

Tabel 1. Hasil Uji Model Faktor Konfirmatori Faktor Eksogen

\begin{tabular}{|c|c|c|c|}
\hline $\begin{array}{l}\text { Indikator } \\
\text { Goodness-of-fit }\end{array}$ & $\begin{array}{l}\text { Nilai } \\
\text { Reko } \\
\text { mend } \\
\text { asi }\end{array}$ & $\begin{array}{l}\text { Hasil } \\
\text { Model }\end{array}$ & Ket. \\
\hline$\chi^{2}$-Chi Square & & 159,677 & \\
\hline $\begin{array}{l}\chi^{2} \text {-Significance } \\
\text { Probability }\end{array}$ & $\geq 0,05$ & 0,006 & Marginal \\
\hline Relatif $\chi^{2}(\mathrm{CMIN} / \mathrm{DF})$ & $\leq 2,00$ & 1,353 & Baik \\
\hline RMSEA & $\leq 0,08$ & 0,05 & Baik \\
\hline GFI & $\geq 0,90$ & 0,884 & Marginal \\
\hline AGFI & $\geq 0,90$ & 0,849 & Marginal \\
\hline TLI & $\geq 0,95$ & 0,958 & Baik \\
\hline $\mathrm{CFI}$ & $\geq 0,95$ & 0,963 & Baik \\
\hline
\end{tabular}

Gambar 1 dan Tabel 1, diketahui bahwa indikator fit $\chi^{2}$-Significance Probability, GFI, dan AGFI dalam kategori marginal, dan indikator fit model yang lain dalam kategori baik. Berdasarkan hal ini, maka model layak diuji pada tahap full model.

Analisis Faktor Konfirmatori Konstruk Endogen

Analisis faktor konfirmatori konstruk endogen digunakan untuk menguji unidimensionalitas pembentuk masing-masing variabel laten. Pada konstruk endogen, terhadap 2 unobserved variable dengan 18 observed variable sebagai pembentuknya. Hasil pengujian analisis faktor konfirmatory atau konstruk eksogen ditunjukkan pada Gambar 2 berikut: 


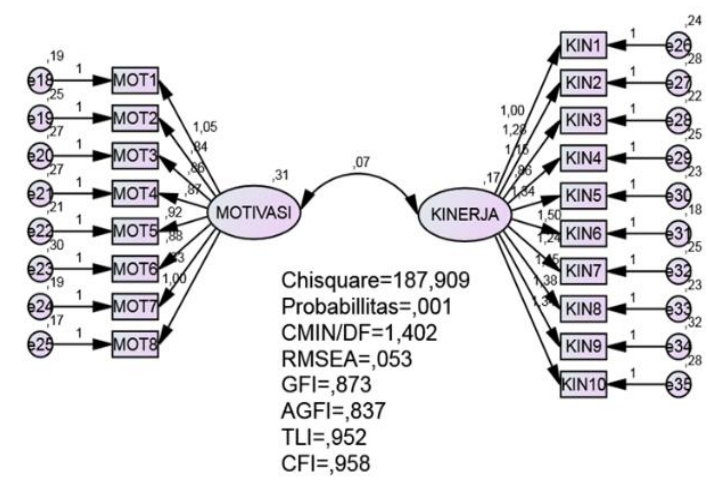

Gambar 2. Model Analisis Faktor Konfirmatori Konstruk Endogen

Hasil uji fit model faktor konfirmatori konstruk eksogen dapat dideskripsikan dalam Tabel 2 berikut:

Tabel 2. Hasil Uji Model Faktor Konfirmatori Faktor Eksogen

\begin{tabular}{llll}
\hline \multicolumn{1}{c}{$\begin{array}{c}\text { Indikator } \\
\text { Goodness-of-fit }\end{array}$} & $\begin{array}{c}\text { Nilai } \\
\text { Rekomenda } \\
\text { si }\end{array}$ & $\begin{array}{c}\text { Hasil } \\
\text { Model }\end{array}$ & Keterangan \\
\hline$\chi^{2}$-Chi Square & & 187,90 & \\
& & 9 & \\
$\chi^{2}$-Significance Probability & $\geq 0,05$ & 0,001 & Tidak Baik \\
Relatif $\chi^{2}$ (CMIN/DF) & $\leq 2,00$ & 1,402 & Baik \\
RMSEA & $\leq 0,08$ & 0,053 & Baik \\
GFI & $\geq 0,90$ & 0,873 & Marginal \\
AGFI & $\geq 0,90$ & 0,837 & Marginal \\
TLI & $\geq 0,95$ & 0,952 & Baik \\
CFI & $\geq 0,95$ & 0,958 & Baik \\
\hline
\end{tabular}

Apabila melihat Gambar 2 dan Tabel 2, diketahui bahwa indikator fit $\chi^{2}$-Significance Probability termasuk kategori tidak baik, GFI, dan AGFI dalam kategori marginal, dan indikator fit model yang lain dalam kategori baik. Berdasarkan hal ini, maka model layak diuji pada tahap full model.

Analisis Structural Equation Modeling (SEM)

Model Structural Equation Modeling (SEM) lengkap pada penelitian ini, dapat digambarkan dalam Gambar 3 berikut:

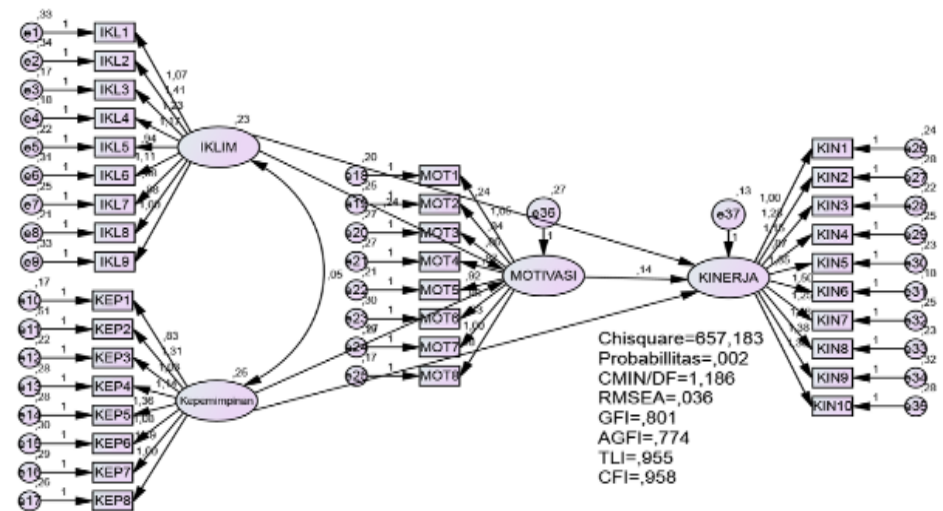

Gambar 3. Full Model Structural Equation Modeling (SEM)

Oktiana, M., Handayani S.D. 2018. Indonesian Journal of Hospital Administration 
Hasil uji model full Structural Equation Modeling (SEM) dapat dideskripsikan dalam Tabel 3 berikut:

Tabel 3. Hasil Uji Full Model Structural Equation Modeling (SEM)

\begin{tabular}{llll}
\hline $\begin{array}{l}\text { Indikator } \\
\text { Goodness-of-fit }\end{array}$ & $\begin{array}{l}\text { Nilai } \\
\text { Rekomenda } \\
\text { si }\end{array}$ & $\begin{array}{l}\text { Hasil } \\
\text { Model }\end{array}$ & Ket. \\
\hline$\chi^{2}$-Chi Square & & 657,183 & \\
$\chi^{2}$-Significance Probability & $\geq 0,05$ & 0,002 & Tidak Baik \\
Relatif $\chi^{2}$ (CMIN/DF) & $\leq 2,00$ & 1,186 & Baik \\
RMSEA & $\leq 0,08$ & 0,036 & Baik \\
GFI & $\geq 0,90$ & 0,801 & Marginal \\
AGFI & $\geq 0,90$ & 0,774 & Marginal \\
TLI & $\geq 0,95$ & 0,955 & Baik \\
CFI & $\geq 0,95$ & 0,958 & Baik \\
\hline
\end{tabular}

Berdasarkan Gambar 3 dan Tabel 3, diketahui bahwa indikator fit $\chi^{2}$-Significance Probability termasuk kategori kurang baik, GFI, dan AGFI dalam kategori marginal, dan indikator fit model yang lain dalam kategori baik. Berdasarkan hal ini, maka model keseluruhan memenuhi kriteria model fit.

Uji Hipotesis

Tahap pengujian hipotesis ini adalah untuk menguji hipotesis penelitian diajukan. Pengujian hipotesis ini didasarkan atas pengolahan data penelitian dengan menggunakan analisis SEM. Hasil pengujian hipotesis dapat diringkas dalam tabel sebagai berikut:

Pengujian Hipotesis Pertama

Hasil analisis didapatkan nilai c.r untuk pengaruh iklim organisasi terhadap motivasi kerja sebesar 2,218 dan $p$ sebesar 0,027. Berdasarkan nilai c.r $>1,96$ dan $p<0,05$, maka hipotesis pertama (Ha1) diterima, sehingga disimpulkan bahwa ada pengaruh yang signifikan iklim organisasi terhadap motivasi kerja perawat di RS PKU Muhammadiyah Yogyakarta Unit II.

Pengujian Hipotesis Kedua

Hasil analisis didapatkan nilai c.r untuk pengaruh kepemimpinan terhadap motivasi kerja sebesar 2,528 dan $p$ sebesar 0,011. Berdasarkan nilai c.r $>1,96$ dan $p<0,05$, makahipotesis kedua (Ha2) diterima, sehingga disimpulkan bahwa ada pengaruh yang signifikan kepemimpinan terhadap motivasi kerja perawat di RS PKU Muhammadiyah Yogyakarta Unit II.

\section{Pengujian Hipotesis Ketiga}

Hasil analisis didapatkan nilai c.r untuk pengaruh motivasi kerja terhadap kinerja sebesar 1,987 dan $p$ sebesar 0,047. Berdasarkan nilai c. $r>1,96$ dan $p<0,05$, maka hipotesis ketiga (Ha3) diterima, sehingga disimpulkan bahwa ada pengaruh yang signifikan motivasi kerja terhadap kinerja perawat di RS PKU Muhammadiyah Yogyakarta Unit II.

Pengujian Hipotesis Keempat 
Hasil analisis didapatkan nilai c.r untuk pengaruh iklim organisasi terhadap kinerja sebesar 2,935 dan $p$ sebesar 0,003. Berdasarkan nilai c.r $>1,96$ dan $p<0,05$, disimpulkan bahwa ada pengaruh yang signifikan iklim organisasi terhadap kinerja perawat di RS PKU Muhammadiyah Yogyakarta Unit II.

Pengujian Hipotesis Kelima

Hasil analisis didapatkan nilai c.r untuk pengaruh kepemimpinan terhadap kinerja sebesar 2,271 dan $p$ sebesar 0,023. Berdasarkan nilai c. $r>1,96$ dan $p<0,05$, maka hipotesis kelima (Ha5) diterima, sehingga disimpulkan bahwa ada pengaruh yang signifikan kepemimpinan terhadap kinerja perawat di RS PKU Muhammadiyah Yogyakarta Unit II.

Selanjutnya untuk menguji hipotesis 6 dan 7, dilakukan dengan membandingkan pengaruh langsung dan pengaruh tidak langsung. Pengaruh langsung ditunjukkan pada standardized direct effect, dan pengaruh tidak langsung ditunjukkan dalam standardized indirect effect. Pengaruh langsung (standardized direct effect) dideskripsikan dalam Tabel 4 berikut:

Tabel 4. Pengaruh Langsung (Standardized Direct Effect)

\begin{tabular}{cccc}
\hline & Kepemimpinan & Iklim & Motivasi \\
\hline Motivasi & 0,239 & 0,208 & 0,000 \\
Kinerja & 0,211 & 0,282 & 0,183 \\
\hline
\end{tabular}

Adapun pengaruh tidak langsung standardized indirect effect, dideskripsikan dalam Tabel 5 berikut:

Tabel 5. Pengaruh Tidak Langsung Standardized Indirect Effect

\begin{tabular}{cccc}
\hline & Kepemimpinan & Iklim & Motivasi \\
\hline Motivasi & 0,000 & 0,000 & 0,000 \\
Kinerja & 0,044 & 0,038 & 0,000 \\
\hline
\end{tabular}

Berdasarkan Tabel 4 dan 5 dilakuan pengujian hipotesis keenam dan ketujuh sebagai berikut: Pengujian Hipotesis Keenam

Tabel 4 menunjukkan bahwa nilai standardized direct effect pengaruh iklim organisasi terhadap kinerja adalah sebesar 0,282. Adapun tabel 5 menunjukkan bahwa nilai standardized indirect effect pengaruh iklim organisasi terhadap kinerja dengan melalui motivasi kerja sebagai variabel intervening, sebesar 0,038 . Berdasarkan nilai standardized direct effectyang lebih besar, maka Ha6 ditolak, sehingga disimpulkan bahwa pengaruh iklim organisasi terhadap kinerja perawat merupakan pengaruh langsung.

Pengujian Hipotesis Ketujuh

Tabel 4 menunjukkan bahwa nilai standardized direct effect pengaruh kepemimpinan terhadap kinerja adalah sebesar 0,211. Adapun tabel 4 menunjukkan bahwa nilai standardized indirect effect pengaruh kepemimpinan terhadap kinerja dengan melalui motivasi kerja sebagai variabel intervening, sebesar 0,044 . Berdasarkan nilai standardized 
indirect effect yang lebih besar, sehingga disimpulkan bahwa pengaruh kepemimpinan terhadap kinerja perawat merupakan pengaruh langsung.

\section{Pembahasan}

Hasil penelitian menunjukkan bahwa ada pengaruh yang signifikan iklim organisasi terhadap motivasi kerja perawat di RS PKU Muhammadiyah Yogyakarta Unit II. Hasil penelitian mendukung hasil penelitian Forehand \& Gilmer (3) menyatakan bahwa iklim organisasi adalah seperangkat karakteristik yang menggambarkan sebuah organisasi dan yang (a) membedakan satu organisasi dari organisasi lain; (b) relatif bertahan dari waktu ke waktu dan (c) mempengaruhi perilaku orang-orang dalam organisasi. Hasil penelitian menunjukkan bahwa ada pengaruh yang signifikan kepemimpinan terhadap motivasi kerja perawat di RS PKU Muhammadiyah Yogyakarta Unit II. Hasil penelitian ini mendukung hasil penelitian Prasastono (4). Kepemimpinan (leadership) merupakan proses mengarahkan dan mempengaruhi aktivitas yang berkaitan dengan pekerjaan dari para karyawannya. Kepemimpinan adalah proses mempengaruhi dalam menentukan tujuan organisasi, memotivasi perilaku pengikutnya untuk mencapai tujuan dan mempengaruhi kelompok dan budayanya (4).

Hasil penelitian menunjukkan bahwa ada pengaruh yang signifikan motivasi kerja terhadap kinerja perawat di RS PKU Muhammadiyah Yogyakarta Unit II. Hasil penelitian ini mendukung hasil penelitian Salleh et al (5); Latief (2012); dan Zameer et al (6). Hasil penelitian menunjukkan bahwa ada pengaruh yang signifikan iklim organisasi terhadap kinerja perawat di RS PKU Muhammadiyah Yogyakarta Unit II. Hasil penelitian ini mendukung hasil penelitian Media (7). Iklim organisasi yang baik dalam bekerja menimbulkan kenyamanan, saling menghormati, dan kebersamaan dalam bekerja. Idealnya, dengan sendirinya jika orang telah merasa nyaman dengan pekerjaannya, maka akan meningkatkan kualitas kerjanya (8).

Hasil penelitian menunjukkan bahwa ada pengaruh yang signifikan kepemimpinan terhadap kinerja perawat di RS PKU Muhammadiyah Yogyakarta Unit II. Hasil penelitian ini mendukung hasil penelitian Media (7). Keberadaan pemimpin di tengah-tengah karyawan seperti perawat sangat diperlukan.Kepemimpinan yang ideal adalah bila mana tujuan dan keputusan kerja dibuat bersama dalam kelompok. Pemimpin yang baik adalah yang mampu menggerakkan perawat untuk dapat melaksanakan asuhan keperawatan dengan baik (1).

Hasil penelitian menunjukkan bahwa pengaruh iklim organisasi terhadap kinerja perawat merupakan pengaruh langsung. Hal ini menunjukkan bahwa iklim organisasi di RS PKU Muhammadiyah Yogyakarta Unit II sangat mendukung iklim kerja perawat, sehingga akan berpengaruh terhadap peningkatan kinerja. RS PKU Muhammadiyah Yogyakarta Unit II telah mampu memberikan penghargaan dan umpan balik (recognition and feedback); 
mempunyai manajemen (management) yang baik, dalam organisasi terjalin hubungan kerja (work relationships) yang baik, harmonis dan saling mendukung, karakteristik tugas (task characteristics) yang menantang, pembagian tanggung jawab (responsibility) yang jelas, beban kerja (work pressure) sesuai dengan tupoksinya; serta perawat diberikan kebebasan untuk mengambil keputusan (decision-making) sesuai tanggung jawabnya.

Hasil penelitian menunjukkan bahwa pengaruh kepemimpinan terhadap kinerja perawat merupakan pengaruh langsung. Hal ini menunjukkan bahwa kepemimpinan di RS PKU Muhammadiyah Yogyakarta Unit II memang ditujukan untuk meningkatkan kinerja perawat. Pengaruh pemimpin, stimulasi intelektual dan pertimbangan-pertimbangan profesional yang dilakukan terhadap perawat, menyebabkan perawat semakin memahami cara melaksanakan pekerjaan secara lebih baik, sehingga kinerjanya juga meningkat.

\section{SIMPULAN DAN SARAN}

Ada pengaruh yang signifikan iklim organisasi, kepemimpinan terhadap motivasi kerja perawat di RS PKU Muhammadiyah Yogyakarta Unit II. Ada pengaruh yang signifikan motivasi kerja, iklim organisasi, kepemimpinan terhadap kinerja perawat di RS PKU Muhammadiyah Yogyakarta Unit II. Pengaruh iklim organisasi terhadap kinerja perawat merupakan pengaruh langsung. Pengaruh kepemimpinan terhadap kinerja perawat merupakan pengaruh langsung.

\section{DAFTAR PUSTAKA}

1. Mulyono $\mathrm{MH}$, Hamzah A, Abdullah AZ. Faktor Yang Berpengaruh Terhadap Kinerja Perawat di Rumah Sakit Tingkat III 16.06.01 Ambon. J AKK. 2013;2(1):18-26.

2. Broni AA. Relationship between Motivation and Job Performance at the University of Mines and Technology, Tarkwa, Ghana: Leadership Lessons. J Creat Educ. 2012;3(3):309-14.

3. Ali A, Patnaik B. Influence of Organizational Climate and Organizational Culture on Managerial Effectiveness: An Inquisitive Study. Carringt Rand J Soc Sci. 2014;1(2):1-20.

4. Prasastono, Ndaru. Pengaruh Gaya Kepemimpinan dan Kompensasi Terhadap Motivasi Kerja Karyawan Hotel Muria Semarang. J Din Kepariwisataan. 2012;XI(2):32-9.

5. Salleh F, Dzulkifli Z, Abdullah WAW, Yaakob NHM. The Effect of Motivation on Job Performance of State Government Employees in Malaysia. Int J Humanit Soc Sci. 2011;1(4):147-54.

6. Zameer H, Ali S, Nisar W, Amir M. The Impact of the Motivation on the Employee's Performance in Beverage Industry of Pakistan. Int J Acad Res Accounting, Financ Manag Sci. 2014;4(1):293-298.

7. Media L. Pengaruh Kepemimpinan Partisipatif dan Iklim Organisasi Terhadap Kinerja Pegawai Kantor X. In: Seminar Nasional Sistem Informasi Indonesia. 2013.

8. Aryansah I, Kusumaputri ES. Iklim Organisasi dan Kualitas Kehidupan Kerja Karyawan. J Humanit. 2013;X(1):75-86. 